\title{
ANALISIS KESESUAIAN MATERI BUKU TEKS BAHASA INDONESIA SMP/MTS KELAS VII DENGAN KARAKTERISTIK SISWA KELAS VII A7 DI SMPN 1 SINGARAJA
}

\author{
Ni Made Gita Pramana ${ }^{1}$,Sang Ayu Putu Sriasih ${ }^{2,}$ Gede Gunatama ${ }^{3}$ \\ Jurusan Pendidikan Bahasa dan Sastra Indonesia, Fakultas Bahasa dan Seni \\ Universitas Pendidikan Ganesha \\ Singaraja, Indonesia \\ e-mail:\{gitapramananimade@gmail.com,sap.sriasih@yahoo.com, \\ gedegunatama22@gmail.com \}
}

\begin{abstract}
Abstrak
Penelitian ini bertujuan untuk (1) mendeskripsikan kesesuaian materi buku teks Bahasa Indonesia SMP/MTs Kelas VII Kurikulum 2013 dengan tuntutan kurikulum dan (2) Mendeskripsikan kesesuaian materi buku teks Bahasa Indonesia SMP/MTs Kelas VII Kurikulum 2013 dengan karakteristik siswa kelas VII A7 di SMPN 1 Singaraja. Subjek pada penelitian ini adalah buku teks Bahasa Indonesia SMP/MTs Kelas VII Kurikulum 2013 edisi revisi, siswa kelas VII A7, dan guru mata pelajaran bahasa Indonesia di SMP Negeri 1 Singaraja. Objek penelitian ini adalah materi buku teks bahasa Indonesia SMP/MTs kelas VII. Metode pengumpulan data yang digunakan adalah metode dokumentasi silabus mata pelajaran bahasa Indonesia jenjang SMP kelas VII. Penelitian ini menggunakan instrument wawancara untuk mengetahui kesesuaian materi buku teks bahasa Indonesia SMP/MTs kelas VII Kurikulum 2013 dengan karakteristik siswa kelas VII A7 di SMPN 1 Singaraja. Data dianalisis dengan menggunakan teknik deskriptif kualitatif. Hasil penelitian ini adalah (1) tedapat beberapa materi yang kurang sesuai dengan KI 3 dan KI 4 dalam Kurikulum 2013. Di samping itu, peneliti menemukan kekurangsesuaian pada penilaian autentik kompetensi pengetahuan dan kompetensi keterampilan.dan (2) materi buku teks bahasa Indonesia SMP/MTs kelas VII Kurikulum 2013 edisi revisi 2017 sesuai dengan karakteristik siswa kelas VII A7 di SMPN 1 Singaraja, walaupun belum secara maksimal. Peneliti berharap peneliti lain dapat melakukan penelitian yang berkaitan dengan permasalahan tingkat keterbacaan, kemudahan, dan keterpahaman buku teks. Selain itu, objek lain yang dapat diteliti, yaitu unsur kebahasaan buku teks yang dilihat dari beberapa aspek.
\end{abstract}

Kata Kunci: materi, kurikulum 2013, karakteristik siswa SMP

\begin{abstract}
This research has purposes to (1) describe the suitability of the Indonesian textbook material in the SMP/MTs at the seventh grade students in the Curriculum 2013 to the curriculum demands, and (2) describe the suitability of Indonesian textbook material in the SMP/MTs at the seventh grade students in the Curriculum 2013 to the students' characteristics of the VII A7 class at SMPN 1 Singaraja. The subjects of this research are the Indonesian textbook material in the SMP/MTs at the seventh grade students in the Curriculum 2013 in the revision edition, the students of VII A7 class, and the Indonesian teacher at SMPN 1 Singaraja. The object of the research is the Indonesian textbook material in the SMP/MTs at the seventh grade. The method of data collection which is used is the documentation of Indonesian syllabus at the seventh grade of junior high school method. This
\end{abstract}


Volume 8 Nomor 1, Februari 2018

P-ISSN : 2614-4743 (cetak) dan e-ISSN : 2614-2007 (online)

research uses interview as the instrument to know the suitability of Indonesian textbook material in the SMP/MTs at the seventh grade students in the Curriculum 2013 to the students' characteristics of the VII A7 class at SMPN 1 Singaraja. The data analysis uses descriptive qualitative technique. The result of the research are (1) it is found that some materials are not appropriate to the $\mathrm{KI} 3$ and $\mathrm{KI} 4$ in the curriculum 2013. Beside that, the researcher founds the incompability of the authentic assessment of knowledge competence to the skill competence, and (2) the Indonesian textbook material in the SMP/MTs at the seventh grade students in the Curriculum 2013 in the revision edition in 2017 is appropriate to the students' characteristics of the VII A7 at SMPN 1 Singaraja, although it is not maximal. The researcher hopes that the other researchers can do a research which is related to the problems of reading level, convenience, and the understanding of textbook. Besides, the other objects that can be investigated are the elements of linguistics textbook that can be seen from some aspects.

Keywords: material, curriculum 2013, the characteristics of junior high school students

\section{PENDAHULUAN}

Pendidikan adalah usaha sadar dan terencana untuk mewujudkan suasana belajar dan proses pembelajaran agar peserta didik aktif mengembangkan potensi dirinya (Pengertian pendidikan, Bab I, 1(1) Undang-undang Sisdiknas No. 20 tahun 2003) dalam Utomo Dananjaya (2013:24). Inilah misi pendidikan yang harus diemban oleh seluruh masyarakat dan pemerintah Indonesia. Pemerintah dalam otoritasnya berhak menentukan kebijakan dalam meningkatkan mutu pendidikan, salah satunya merancang dan menentukan kurikulum.

Kurikulum mempunyai kedudukan sentral dalam pendidikan di Indonesia karena kurikulum mengarahkan segala bentuk aktivitas pendidikan untuk mencapai tujuan negara, yaitu mencerdaskan kehidupan bangsa. Hal tersebut terbukti dengan usaha keras kementerian pendidikan yang merancang dan memberlakukan kurikulum sesuai dengan kebutuhan masyarakat Indonesia. Indonesia sudah beberapa kali mengalami pergantian kurikulum, yaitu pada tahun 1947, 1952, 1964, 1968, 1975, 1984, 1994, 2004, dan tahun 2006 (Sholeh Hidayat, 2013:1). Perubahan tersebut merupakan konsekuensi dan implikasi terjadinya perubahan sistem politik, sosial budaya, ekonomi, serta perkembangan iptek. Perkembangan iptek dewasa ini menjadi dampak yang paling berpengaruh bagi pendidikan sehingga dirancang dan diberlakukanlah kurikulum tahun 2013 atau disebut Kurikulum 2013.
Kurikulum 2013 digadang-gadang memiliki kelebihan dalam mengatasi sejumlah masalah yang dihadapi dunia pendidikan. Di samping itu, secara konseptual Kurikulum 2013 dicita-citakan untuk mampu melahirkan generasi masa depan yang cerdas komprehensif, yakni tidak hanya cerdas intelektualnya, tetapi juga cerdas emosi, sosial, dan spiritualnya. Hal tersebut tampak dengan terintegrasikannya nilai-nilai karakter ke dalam proses pembelajaran, tidak lagi menjadi suplemen seperti dalam Kurikulum Tingkat Satuan Pendidikan (KTSP). KTSP menjadi dasar pijak pengembangan kurikulum baru ini, tetapi terdapat berapa terobosan baru, salah satunya adalah SK dan KD yang berubah menjadi KI dan KD dalam Kurikulum 2013 dirumuskan dan ditetapkan oleh pusat.

Ditetapkannya Kurikulum 2013 tentu mendapat berbagai sambutan dari masyarakat, baik positif maupun negatif. Pendapat positif yang dikemukakan oleh masyarakat tetang Kurikulum 2013, yaitu kurikulum ini merupakan terobosan baru dan menilai peserta didik secara komprehensip, sehingga lulusan yang akan dihasilkan diharapkan sesuai dengan harapan bangsa (memiliki kecerdasan ilmu, mental, serta memiliki keterampilan yang mumpuni). Akan tetapi, seperti kata pepatah, tak ada gading yang tak retak. Pemberlakuan Kurikulum 2013 juga mendapatkan banyak hujatan dan pandangan negatif. Terlebih lagi, kementerian pendidikan dasar dan menengah memutuskan meninjau kembali penggunaan Kurikulum 2013. Kebijakan 
Volume 8 Nomor 1, Februari 2018

P-ISSN : 2614-4743 (cetak) dan e-ISSN : 2614-2007 (online)

tersebut membingungkan semua lapisan masyarakat dan mempertanyakan langkah yang harus diambil selanjutnya. Terutama pada sekolah-sekolah yang sudah menerapkan Kurikulum 2013. Sejalan dengan hal itu, pemerintah juga harus mempertimbangkan kebutuhan penting pendidik dan peserta didik yang dirancang dan dibuat oleh pusat, yaitu buku teks.

Buku teks merupakan salah satu jenis bahan ajar yang dapat dimanfaatkan oleh guru dan siswa dalam proses belajarmengajar (PBM). Menurut Mudlofir (2011:37) masalah penting yang sering dihadapi dalam kegiatan pembelajaran adalah memilih atau menentukan materi pembelajaran atau bahan ajar yang tepat dalam rangka membantu siswa mencapai kompetensi. Mahmood (dalam Mulyasa, 2011:37) menyatakan pemilihan buku yang sesuai adalah proses yang membutuhkan perhatian. PBM berlangsung secara efektif jika ada buku atau bahan ajar. Tidak membawa buku siswa keluar, membawa buku siswa terancam tidak mendapat uang jajan, karena harga buku yang kurang terjangkau. Setidaknya hal itulah yang menjadi fenomena nyata dalam praktik belajar-mengajar jika kebijakan memilih bahan ajar ditentukan oleh guru.

Sebuah penelitian menyatakan buku teks yang digunakan di dalam pembelajaran masih dapat digunakan sebagai sumber media pembelajaran di sekolah namun harus didukung oleh bukubuku lain sehingga materi yang disampaikan dapat mencapai standar kompetensi dan kompetensi dasar. Sholeh (2006:45) mengemukakan bahwa bahan pembelajaran yang terdapat dalam kurikulum belum sepenuhnya tersaji dalam buku ajar. Selain itu terdapat pula bahan pembelajaran yang tidak terdapat dalam kurikulum namun terdapat dalam buku ajar. Oleh karena itu, sekolah maupun dinas pendidikan harus menyediakan buku teks yang relevan dengan kurikulum sehingga buku tersebut dapat meningkatkan kualitas pendidikan.

Akan tetapi dalam implementasi Kurikulum 2013 pemerintah tampaknya memberi angin segar bagi pendidik dan peserta didik dalam meringankan beban tersebut dengan menerapkan kebijakan pengadaan buku teks yang berkualitas. Kualitas buku teks harus memperhatikan aspek penting, yaitu kesesuaian materi dengan kurikulum. Bahan ajar merupakan salah satu komponen sistem pembelajaran yang memegang peranan penting dalam membantu siswa mencapai standar kompetensi dan kompetensi dasar (Mudlofir, 2011:21). Buku teks juga harus memenuhi aspek kesesuaian dengan kecukupan materi yang terkandung di dalamnya, kedalaman materi pengayaan, penerapan pendekatan saintifik, dan Penilaian autentik yang tersedia dalam buku siswa. Selain itu, buku teks harus secara jelas mengomunikasikan informasi, konsep, dan pengetahuan sehingga dapat dipahami oleh pendidik dan peserta didik. Dengan kata lain buku teks dapat memberi solusi masalah belajar sesuai dengan mata pelajaran tertentu, salah satunya adalah bahasa Indonesia.

Bahasa Indonesia ditempatkan sebagai penghela mata pelajaran lain, karena itu bahasa Indonesia digunakan sebagai pengantar seluruh mata pelajaran. Apabila peserta didik tidak menguasai mata pelajaran tertentu harus dipastikan bahwa yang tidak dikuasai adalah salah satu bagian mata pelajaran tersebut, bukan karena kelemahan penguasaan bahasa pengantar yang dipergunakan. Sejalan dengan hal itu, disusunlah buku yang berbasis teks, yaitu buku siswa mata pelajaran bahasa Indonesia untuk SMP/MTs kelas VII. Mengingat pentingnya kedudukan bahasa Indonesia sebagai bahasa pengantar pelajaran lain, maka buku siswa mata pelajaran bahasa Indonesia untuk SMP/MTs kelas VII, seharusnya sudah sesuai dengan kebutuhan dan tuntutan Kurikulum 2013. Akan tetapi dalam pelaksanaannya, buku ini menjadi bahan yang pertama dan satusatunya yang dikeluarkan oleh pemerintah guna mendukung implementasi Kurikulum 2013 yang sudah diterapkan dibeberapa sekolah di Indonesia. Beberapa sekolah yang yang masih menerapkan Kurikulum 2013 tetap memakai buku teks tersebut untuk menghindari kebingungan siswa 
Volume 8 Nomor 1, Februari 2018

P-ISSN : 2614-4743 (cetak) dan e-ISSN : 2614-2007 (online)

dalam memahami materi yang terkandung dalam buku.

Sejumlah materi yang terkandung dalam buku teks, khususnya buku teks bahasa Indonesia Kelas VII seyogianya sudah sesuai dengan kurikulum dan karakteristik siswa. Akan tetapi beberapa siswa, bahkan guru mengeluhkan sulitnya memahami beberapa materi dalam buku teks siswa Kurikulum 2013. Di samping itu, siswa dituntut membaca, membaca, dan membaca, serta dituntut berperan aktif dalam proses pembelajaran. Kenyataannya beberapa sekolah belum terbiasa dengan proses belajar-mengajar dalam rangka menerapkan Kurikulum 2013, khususnya sekolah yang baru mendapat sosialisasi mengenai Kurikulum 2013. Akibatnya, Kurikulum 2013 tidak berlaku secara menyeluruh disemua sekolah di Indonesia.

Untuk menjawab masalah kesesuaian materi dalam buku teks siswa dengan karakteristik perkembangan siswa, peneliti perlu melakukan penelitian karena kesesuaian materi dengan buku teks dengan karakteristik siswa akan berdampak baik bagi guru dan siswa dalam pemanfaatan buku teks sebagai sumber belajar mengajar. Oleh karena itu, peneliti mengangkat masalah yang berjudul "Analisis Kesesuaian Materi Buku Teks Bahasa Indonesia SMP/MTs Kelas VII Kurikulum 2013 dengan Karakteristik Siswa Kelas VII A7 di SMPN 1 Singaraja". Peneliti memilih melakukan penelitian di SMP Negeri 1 Singaraja karena salah satu sekolah yang masih menerapkan Kurikulum 2013 adalah SMPN 1 Singaraja. Mengutip salah satu berita Buleleng Round Up tentang kurikulum 2013, Kadisdik Buleleng Dewa Manuaba menyatakan bahwa SMPN 1 Singaraja merupakan salah satu sekolah yang menerapkan Kurikulum 2013 sebagai pilot project. Dari observasi awal, SMPN 1 Singaraja memakai buku teks yang diterbitkan oleh pemerintah sebagai sumber utama bagi guru dan siswa. Akan tetapi, menurut penuturan salah satu mahasiswa yang telah melakukan PPLReal di SMP tersebut, beberapa materi dalam buku teks siswa masih agak sulit dipahami siswa. Oleh karena itu, perlu dilakukan penelitian mengenai analisis kesesuain buku teks siswa ini untuk mengetahui kesesuaian materi dengan perkembangan siswa sehingga menjadi pertimbangan bagi guru dalam memilih variasi bahan ajar.

Penelitian ini akan dilakukan di kelas VII A7 karena pada kelas tersebut rata-rata kemampuan akademik siswa berada pada level menengah. Pendapat yang diuraikan siswa di kelas VII A7 digunakan untuk memperkuat data kesesuaian buku teks dengan karakteristik siswa. Selain itu, peneliti melakukan batasan terhadap kesesuaian materi dengan karakteristik siswa. Karakteristik yang dimaksud adalah karakteristik siswa kelas VII yang memasuki fase remaja awal. Danim (2011:29) mengatakan bahwa masa remaja merupakan masa transisi, yaitu periode peralihan antara masa kanak-kanak dan dewasa. Periode ini memiliki ciri khas yang disebut masa pubertas. Pada periode ini siswa mulai menunjukkan proses pertumbuhan dan perkembangan yang sangat signifikan. Akan tetapi peneliti membatasi masalah penelitian pada karakteristik kognitif siswa, afektif, dan psikomotor siswa. Penelitian ini akan menganalisis kesesuaian materi dengan kurikulum (terdapat pada silabus) dan karakteristik siswa, sehingga masalah yang diangkat peneliti merupakan masalah yang benar-benar baru.

Penelitian yang berjudul "Analisis Kesesuaian Materi Buku Teks Bahasa Indonesia SMP/MTs Kelas VII Kurikulum 2013 dengan Karakteristik Siswa Kelas VII A 7 di SMPN 1 Singaraja" perlu dilakukan karena dapat memperluas wawasan penelitian yang telah ada. Di samping itu, penelitian mengenai analisis kesesuaian materi yang terkandung dalam buku siswa jarang ada yang meneliti. Terdapat penelitian sejenis dengan penelitian yang akan peneliti lakukan. Penelitian sejenis tersebut adalah yang oleh $\mathrm{Ni}$ Nyoman Trenis pada tahun 2012 yang berjudul "Kesalahan Bahasa Indonesia dalam Buku Teks 'IPS Terpadu' Karya Tim Abdi Guru Penerbit Erlangga". Penelitian tersebut dirancang dalam bentuk penelitian 
Volume 8 Nomor 1, Februari 2018

P-ISSN : 2614-4743 (cetak) dan e-ISSN : 2614-2007 (online)

deskriptif kualitatif dan kuantitatif. Subjek penelitian tersebut adalah Buku Teks IPS Terpadu Karya Tim Abdi Guru Penerbit Erlangga. Penelitian yang dilakukan oleh mahasiswa Undiksha tersebut bertujuan menemukan kesalahan bahasa dalam buku teks tersebut. Penelitian lainnya adalah yang dilakukan oleh Amrih Prayoga pada tahun 2011 yang berjudul "Analisis Kelayakan Isi Buku Teks Pelajaran Fisika SMA". Penelitian ini menggunakan rancangan penelitian deskriptif kualitatif. Subjek penelitian tersebut adalah Buku Teks Pelajaran Fisika SMA. Penelitian yang dilakukan oleh mahasiswa IAIN Walisongo Semarang tersebut bertujuan mendeskripsikan kesesuaian buku teks pelajaran fisika SMA yang diterbitkan oleh beberapa penerbit. Selain itu, penelitian sejenis mengenai kesesuaian materi buku teks juga dilakukan Halida Eka Nurmutia pada tahun 2013 yang berjudul "Analisis Materi, Penyajian, dan Bahasa Buku Teks Matematika Kelas X Di Kabupaten Rembang Tahun Ajaran 2012/2013". Penelitian ini menggunakan rancangan penelitian deskriptif kualitatif. Subjek penelitian tersebut adalah Buku Teks Matematika Kelas $X$ di Kabupaten Rembang tahun Ajaran 2012/2013. Penelitian yang dilakukan oleh mahasiswa UNES tersebut menggunakan rancangan penelitian deskriptif kuantitatif dan bertujuan mendeskripsikan materi, penyajian, dan bahasa buku teks tersebut.

Ketiga penelitian di atas memiliki persamaan dengan penelitian yang dilakukan peneliti. Persamaan tersebut adalah sama-sama mengkaji buku teks dan menggunakan rancangan penelitian deskriptif kualitatif, khususnya pada penelitian kedua dan ketiga. Walaupun terdapat persamaan ada persamaan antara ketiga penelitian di atas, tampak jelas lebih banyak perbedaannya. Perbedaannya adalah penelitian pertama menggunakan rancangan penelitian deskriptif kualitatif dan kuantitatif, sedangkan penelitian ini menggunakan penelitian deskriptif kualitatif. Perbedaannya juga terletak pada subjek penelitian, lokasi penelitian, dan rumusan masalah penelitian. Subjek penelitian ini adalah guru bahasa Indonesia dan siswa kelas VII A7 di SMPN 1 Singaraja. Penelitian yang peneliti lakukan berfokus pada kesesuaian materi buku teks siswa dengan perkembangan kognitif, afektif, dan psikomotor siswa. Penelitian mengenai analisis kesesuaian materi dengan perkembangan siswa ini berbeda dan belum pernah diteliti. Dengan demikian, penelitian ini penting dilakukan untuk seseorang yang berkecimpung di bidang pendidikan, khususnya pendidik dalam memilih bahan ajar, salah satunya adalah buku teks.

Hasil dari penelitian ini diharapkan memberikan manfaat bagi pemerintah, guru bahasa Indonesia, mahasiswa, peneliti lain.

\section{METODE PENELITIAN}

Penelitian ini menggunakan rancangan deskriptif kualitatif. Penelitian ini dapat mengklarifikasi mengenai kesesuaian materi buku teks bahasa Indonesia SMP/MTs kelas VII Kurikulum 2013 dengan karakteristik siswa kelas VII A7 di SMPN 1 Singaraja.

Subjek dalam penelitian ini adalah buku teks bahasa Indonesia SMP/MTs kelas VII Kurikulum 2013, siswa kelas VII A7 di SMPN 1 Singaraja dan guru mata pelajaran bahasa Indonesia kelas VII A7 di SMPN 1 Singaraja. Objek penelitian ini adalah kesesuaian materi buku bahasa Indonesia SMP/MTs Kurikulum 2013 dengan tuntutan kurikulum dan karakteristik siswa kelas VII A7 di SMPN 1 Singaraja.

Penelitian ini mengunakan satu metode pengumpulan data, yaitu metode dokumentasi, wawancara, dan kuesioner. Metode dokumentasi ini digunakan untuk memperoleh data tentang kesesuaian materi buku teks bahasa Indonesia SMP/MTs kelas VII dengan tuntutan Kurikulum 2013 dan kesesuaian materi buku teks bahasa Indonesia SMP/MTs kelas VII dengan karakteristik siswa kelas VII A7 di SMPN 1 Singaraja. Adapun dokumen dalam penelitian ini berupa silabus dan nilai yang ditunjukkan oleh guru dalam pembelajaran. Dalam 
Volume 8 Nomor 1, Februari 2018

P-ISSN : 2614-4743 (cetak) dan e-ISSN : 2614-2007 (online)

penelitian ini, metode observasi digunakan untuk memperoleh data mengenai kesesuaian buku teks bahasa Indonesia SMP/MTs kelas VII dengan tuntutan Kurikulum 2013. Metode wawancara dalam penelitian ini bertujuan untuk mengakuratkan data mengenai kesesuaian materi buku teks bahasa Indonesia SMP/MTs dengan karakteristik siswa kelas VII A7 di SMPN 1 Singaraja. Instrumen pada metode ini adalah pedoman wawancara.

Instrumen yang digunakan adalah lembar observasi, pedoman wawancara, dan daftar cocok. Lembar observasi digunakan untuk memperoleh data mengenai rumusan masalah pertama, pedoman wawancara digunakan untuk memperoleh gambaran tentang rumusan masalah ke dua. Sedangkan daftar cocok atau ceklis digunakan untuk menambah keakuratan data yang diperoleh dari hasil observasi dan wawancara.

D Metode analisis data yang digunakan dalam penelitian ini adalah teknik analisis deskriptif kualitatif. Analisis data dalam penelitian ini mencakup empat tahap, yaitu (1) reduksi data, (2) triangulasi (3) penyajian data, dan (4) penarikan simpulan.

Reduksi data dilakukan mulai dari pengumpulan data mengenai analisis kesesuaian materi buku teks bahasa Indonesia SMP/MTs kelas VII edisi revisi dengan tuntutan Kurikulum 2013 dan karakteristik siswa kelas VII A7 di SMPN 1 Singaraja. Setelah data terkumpul, selanjutnya data tersebut diringkas kembali untuk memilih data-data yang diperlukan dan menghilangkan data-data yang tidak diperlukan. Peneliti melakukan pengumpulan data dengan triangulasi, maka peneliti mengumpulkan data yang sekaligus menguji kredibilitas data, yaitu mengecek kredibilitas data dengan berbagai teknik pengumpulan data dari berbagai sumber data. Data-data disajikan dalam bentuk uraian singkat, bagan, tabel, dan sejenisnya. Pada tahap ini, data mengenai kesesuaian materi buku teks siswa bahasa Indonesia dengan tuntutan Kurikulum 2013 dan karakteristik siswa SMP kelas VII A7 di SMPN 1 Singaraja dipaparkan dengan cara deskriptif kualitatif, sesuai dengan rancangan penelitian ini. Penarikan simpulan didasari oleh data yang didapatkan dalam menganalisis kesesuaian buku teks serta hasil wawancara siswa kelas VII A7 dan guru mata pelajaran bahasa Indonesia yang mengajar di kelas tersebut.

\section{HASIL DAN PEMBAHASAN Hasil Penelitian}

Peneliti menganalisis kesesuaian silabus dengan materi buku teks bahasa Indonesia untuk siswa SMP/MTs kelas VII Kurikulum 2013 edisi revisi 2017. Buku teks bahasa Indonesia untuk siswa kelas VII Kurikulum 2013 edisi revisi 2017 dibagi menjadi delapan bab. Kedelapan bab tersebut memuat materi yang berbedabeda. Untuk menganalisis materi pada buku teks bahasa Indonesia SMP/MTs kelas VII Kurikulum 2013 edisi revisi 2017, peneliti menggunakan instrumen pedoman observasi. Instrumen ini peneliti sesuaikan dengan Silabus Kurikulum 2013, karena melalui Kompetensi Inti dan silabus, buku teks tersebut dapat dibuat dan diterbitkan. Berikut adalah hasil penelitian yang diperoleh melalui observasi mengenai kesesuaian materi buku teks siswa bahasa Indonesia SMP/MTs kelas VII Kurikulum 2013 edisi revisi 2017 dengan tuntutan Kurikulum 2013, khususnya KI, KD, Pembelajaran Saintifik, dan Penilaian. (Tabel hasil observasi terlampir)

Dari empat $\mathrm{KI}$ yang dimuat dalam silabus, materi dalam buku teks sudah sesuai dengan $\mathrm{KI} 1$ dan $\mathrm{KI} 2$, karena pembelajaran dan penilaian $\mathrm{KI} 1 \mathrm{KI} 2$ dilesapkan pada $\mathrm{KI} 3$ dan $\mathrm{KI}$ 4. Akan tetapi, materi dalam buku teks kurang sesuai dengan $\mathrm{KI} 3$ dan $\mathrm{KI} 4$. Kekurangsesuaian tersebut tercermin pada beberapa materi yang kurang sesuai dengan KD.

$$
\text { Terdapat empat materi yang }
$$

kurang sesuai dengan KD. KD-KD tersebut, yaitu KD 3.3 pada bab 2, KD 3.9 pada bab 5, KD 3.11 pada bab 6, dan KD 
Volume 8 Nomor 1, Februari 2018

P-ISSN : 2614-4743 (cetak) dan e-ISSN : 2614-2007 (online)

4.4 pada bab 2. Keempat materi tersebut kurang sesuai karena tidak dimuat dalam buku teks.

Selanjutnya, kesesuaian materi dengan komponen pendekatan saintifik sudah sangat sesuai dengan tuntutan silabus. Semua komponen pendekatan saintifik menjadi unsur utama yang dilakukan dalam proses belajar-mengajar.

Terakhir, hasil penelitian mengenai penilaian autentik, semua bab dalam buku teks sudah sesuai dengan penilaian kompetensi sikap. Penilaian autentik kompetensi pengetahuan kurang sesuai, karena hanya terdapat tes tulis dan penugasan saja pada semua bab. Selanjutnya, penilaian kompetensi keterampilan pada bab 1 sudah sesuai, sedangkan penilaian kompetensi keterampilan pada bab 2, 3, 4, 5, 6, dan 7 kurang sesuai karena hanya terdapat tes praktik saja, serta penilaian kompetensi keterampilan pada bab 8 juga kurang sesuai karena memuat tes praktik dan proyek.

Data mengenai kesesuaian materi buku teks bahasa Indonesia SMP/MTs Kelas VII dengan karakteristik siswa kelas VII A 7 di SMPN 1 Singaraja, khususnya dengan siswa di kelas tersebut. Siswa di kelas VII A 7 berjumlah 32 orang, sedangkan bab yang dipelajari siswa, yaitu sampai bab V. Oleh karena itu, hasil wawancara guru akan melengkapi jawaban siswa..

Berdasarkan hasil wawancara, materi semua bab sudah sesuai dengan pertanyaan 3, 4, 6, dan 9, tetapi materi tersebut kurang sesuai dengan pertanyan nomor 1, 2, 5, 7, 8, dan 10. Selain itu, materi semua bab sudah mengarahkan siswa untuk berpikir secara deduktif induktif, walaupun hanya satu cara saja yang muncul pada beberapa bab. Hal tersebut juga tercermin dalam kesesuaian materi dengan karakter mengarahkan siswa untuk memiliki 16 sikap positif, walapun hanya disampaikan secara tersirat dan di beberapa bab tidak seluruh sikap dapat dipelajari siswa. Selain itu, melalui mempelajari materi dalam buku teks, siswa sudah dapat memproduksi teks secara mandiri dan berkelompok, walapun tidak semua bab mengarahkan siswa untuk melakukan keduanya. Akan tetapi, terdapat materi pada beberapa bab yang kurang sesuai dengan karakteristik siswa, yaitu materi pada bab 1, 3, 4, 7, dan 8 tidak dapat mengarahkan siswa untuk memahami hal yang bersifat imajinatif, materi pada bab 5 dan 8 tidak dapat mengarahkan siswa untuk menelaah dan menyunting melalui contoh yang ada pada buku, dan materi pada bab $1,5,6$, dan 8 tidak dapat mengarahkan siswa untuk membuat rekonstruksi teks melalui membandingkan teks lain.

\section{Pembahasan}

Sesuai dengan hasil yang dipaparkan di atas, dapat disebutkan bahwa ada beberapa temuan yang diperoleh dalam penelitian ini. Temuantemuan yang dimaksud adalah (1) materi buku teks bahasa Indonesia kelas VII sudah sesuai dengan tuntutan kurikulum, walaupun beberapa materi kurang sesuai $\mathrm{KI}$ yang tercermin dalam KD dan beberapa penilaian autentik tidak dimuat dalam buku teks dan (2) materi buku teks bahasa Indonesia kelas VII kurang dengan karakteristik siswa kelas VII A 7 di SMPN 1 Singaraja.

Berdasarkan hasil penelitian yang telah dipaparkan sebelumnya, materi pada buku teks bahasa Indonesia kelas VII sudah sesuai dengan tuntutan kurikulum, walaupun beberapa materi kurang sesuai $\mathrm{KI}$ yang tercermin dalam $\mathrm{KD}$ dan beberapa penilaian autentik tidak dimuat dalam buku teks. Kesesuaian materi dengan $\mathrm{KI} 1$ dan $\mathrm{KI}$ 2, yaitu sudah sesuai, karena $\mathrm{KI} 1$ dan $\mathrm{KI} 2$ merupakan kompetensi yang dicapai melalui pembelajaran tidak langsung (indirect teaching). Hal tesebut merujuk pada lampiran nomor 2 Permendikbud nomor 24 tahun 2016 tentang kompetensi inti dan kompetensi dasar mata pelajaran bahasa Indonesia SMP/MTs. Di samping itu, penilaian terhadap sikap spiritual dan sikap sosial dilakukan sepanjang proses pembelajaran berlangsung dan berfungsi sebagai pertimbangan guru dalam mengembangkan karakter peserta didik lebih lanjut. Sedangkan kesesuaian materi 
Volume 8 Nomor 1, Februari 2018

P-ISSN : 2614-4743 (cetak) dan e-ISSN : 2614-2007 (online)

dengan $\mathrm{KI} 3$ dan $\mathrm{KI} 4$ tercermin dalam KD$\mathrm{KD}$ yang merupakan penjabaran dari $\mathrm{KI}$ tersebut.

Terdapat $16 \mathrm{KD}$ yang dimuat dalam silabus SMP/Mts kelas VII Kurikulum 2013 edisi revisi 2017. Hampir semua materi dan KD sudah sesuai, tetapi empat di antaranya kurang sesuai. Materi tersebut tidak dimuat dalam buku teks, sehingga materi tersebut harus ditambahkan oleh guru yang bersangkutan dengan cara menjelaskan kepada murid mengguakan contoh-contoh kalimat atau teks. Pertama, pada bab 2 khususnya materi mengenai kalimat tidak langsung tidak terdapat dalam buku teks, sehingga materi tersebut kurang sesuai dengan KD 3.3 (Mengidentifikasi unsur-unsur teks narasi (cerita fantasi) yang dibaca dan didengar.) Kedua, pada bab 2 khususnya materi mengenai ejaan dan tanda baca yang digunakan dalam menyunting teks fantasi tidak dimuat pada bab ini, tetapi dimuat pada bab 1 dan itu pun tidak lengkap, sehingga materi tersebut kurang sesuai dengan KD 4.4 (Menyajikan gagasan kreatif dalam bentuk cerita fantasi secara lisan dan tulis dengan memperhatikan struktur dan penggunaan bahasa.). Ketiga, pada bab 5 materi pada buku teks kurang sesuai dengan KD 3.9 (Mengidentifikasi informasi (pesan, rima, dan pilihan kata) dari puisi rakyat (pantun, syair, dan bentuk puisi rakyat setempat) yang dibaca dan didengar.) karena materi mengenai kalimat pernyataan tidak dimuat dalam buku teks. Terakhir, materi buku teks pada bab 6 kurang sesuai dengan KD 3.11 (Mengidentifikasi informasi tentang fabel/ legenda daerah setempat yang dibaca dan didengar.) karena materi mengenai kata kerja tidak terdapat dalam buku teks.

Dari hasil observasi mengenai kesesuaian materi buku teks dengan pembelajaran khususnya pendekatan saintifik dapat disimpulkan bahwa materi pada semua bab sudah sesuai dengan komponen saintifik. Akan tetapi, komponen atau unsur pendekatan saintifik tidak tersusun secara berurutan. Hal tersebut sejalan dengan perubahan Kurikulum 2013 tahun 2017 yang menyatakan bahwa pedekatan saintifik bukanlah satu-satunya metode saat mengajar dan apabila digunakan maka susunannya tidak harus berurutan (dimuat dalam http://kreatifitastanpabatas 17.blogspot.co.id/2017/08/9-perubahank13-kurikulum-2013-update.html).

Selain itu, dari hasil observasi mengenai penilaian autentik khususnya penilaian sikap, materi pada buku teks sudah sesuai dengan penilaian sikap. Penilaian sikap KI 1 dan KI 2 pada Kurikulum 2013 edisi revisi sudah ditiadakan di setiap mata pelajaran, tetapi penilaian sikap lebih terfikus pada mata pelajaran agama dan PPKN namun KI tersebut tetap dicantumkan pada RPP. Akan tetapi, dalam silabus yang peneliti gunakan untuk menganalisis kesesuaian materi dengan Kurikulum 2013, masih dicantumkan penilaian sikap (berupa penilaian observasi dan jurnal). Hal tersebut menjadi bahan untuk mengembangkan sikap spiritual dan sikap sosial dengan memerhatikan karakteristik, kebutuhan, dan kondisi siswa. Di samping itu, dalam Permendikbud no. 24 tahun 2016 bahwa penumbuhan dan pengembangan kompetensi sikap dilakukan sepanjang proses pembelajaran berlangsung dan dapat digunakan sebagai pertimbangan guru dalam mengembangkan karakter siswa lebih lanjut. Artinya, hasil dari penilaian sikap menjadi salah satu penentu bagi siswa untuk dapat naik ke kelas selanjutnya.

Selanjutnya, kesesuaian materi dengan penilaian kompetensi pengetahuan. Dari ketiga komponen penilaian, hanya penilaian tes tulis dan penugasan saja yang sesuai dengan silabus, sedangkan tes lisan tidak dicantumkan dalam buku teks. Kurniawan (2015:92) menyatakan bahwa penilaian pengetahuan dilakukan dengan dua cara, yaitu tes dan nontes. Teknik tes dilakukan dengan dua cara, yaitu tes tulis dan tes lisan, sedangkan nontes dilakukan dengan cara penugasan. Jika dikaitkan dengan materi dalam buku teks, tidak ada instrumen yang mengarahkan guru untuk menilai siswa dengan cara tes lisan.

Melalui hasil observasi mengenai kesesuaian materi dengan penilaian kompetensi keterampilan dapat 
Volume 8 Nomor 1, Februari 2018

P-ISSN : 2614-4743 (cetak) dan e-ISSN : 2614-2007 (online)

disimpulkan bahwa materi dalam buku teks kurang sesuai dengan penilaian kompetensi keterampilan melalui proyek dan portofolio. Padahal penilaian kompetensi sikap dapat dilakukan melalui tiga cara, yaiu tes praktik, proyek, dan portofolio. Perubahan Kurikulum 2013 edisi revisi 2017 memuat "penghitungan nilai keterampilan ditotal (praktik, produk/proyek, dan portofolio) dan diambil nilai rata-rata. Oleh karena itu, materi pada buku teks kurang sesuai dengan penilaian kompetensi keterampilan karena tidak semua bab mencantumkan instrument yang menilai siswa melalui membuat proyek dan portofolio.

Berdasarkan hasil wawancara yang telah dipaparkan pada subbab sebelumnya, siswa di kelas VII A 7 berjumlah 32 siswa dan bab yang dipelajari, yaitu bab I sampai bab V. Pada bab 1 sampai bab $\mathrm{V}$ tersebut, jawaban siswa dan guru akan dijumlahkan, jika jawaban siswa dan guru menyatakan iya dengan alasan sesuai maka bobot nilainya 1, jika jawabannya iya tetapi alasan kurang sesuai maka bobot nilainya 0,5 , serta jika tidak sesuai maka nilainya 0 . Berikut adalah hasil wawancara siswa dan guru di kelas VII A7 mengenai kesesuaian materi buku teks bahasa Indonesia kelas VII edisi revisi dengan karakteristik siswa.

Pada pertanyaan pertama siswa dan guru memberi jawaban "sesuai" sebanyak $95,45 \%$ serta siswa dan guru yang memberi jawaban "kurang sesuai" sebanyak $4,55 \%$. Artinya, materi pada buku teks sesuai dengan karakteristik siswa, yaitu mengarahkan siswa untuk dapat berpikir secara deduktif dan induktif.

Selanjutnya, materi buku teks masih sesuai dengan karakteristik siswa. Siswa dan guru menjawab "sesuai" sebanyak $86,66 \%$, sedangkan siswa dan guru yang menjawan "tidak sesuai" sebanyak 13,34\%. Hasil tersebut menunjukkan materi dalam buku teks belum maksimal dalam mengarahkan siswa untuk memahami hal yang bersifat imajinatif.

Hasil wawancara pada soal ketiga menunjukkan materi buku teks sesuai dengan karakteristik siswa. Siswa dan guru menjawab "sesuai" sebanyak 7,57\%, sedangkan siswa dan guru menjaawab "kurang sesuai" sebanyak $2,43 \%$. Hasil penelitian tersebut menunjukkan materi dalam buku teks mengarahkan siswa untuk dapat menarik kesimpulan.

Kesesuaian materi buku teks dengan karakteristik siswa kelas VII A 7 dan guru mata pelajaran di kelas tersebut menunjukkan tanggapan yang beragam. Pada pertanyaan keempat, sebanyak 83,33\% menjawab "sesuai", sedangkan sebanyak 16,67\% menjawab "kurang sesuai". Dengan demikian, materi dalam buku teks belum secara maksimal mengarahkan siswa memiliki kecerdasn ganda.

Kesesuaian selanjutnya, yaitu menyatakan bahwa materi buku teks sudah sesuai dengan karkteristik siswa SMP kelas VII A7. Sebanyak 86,67\% siswa dan guru yang menjawab "sesuai" sedangkan sebanyak 13,33\% siswa dan guru menjawab "kurang sesuai". Melalui persentase tersebut, materi dalam buku teks sudah sesuai dengan karakteristik siswa. Materi dalam buku teks dapat mengarahkan siswa untuk memiliki 16 sikap positif.

Materi buku teks sudah sesuai dengan karakteristik siswa terdapat dalam pertanyaan keenam. Sebanyak 95,15\% siswa dan guru menjawab "sesuai", sedangkan 4,85\% siswa dan guru menjawab "kurang sesuai". Hal tersebut berarti materi pada buku teks bahasa Indonesia kelas VII edisi revisi sudah sesuai dengan karakteristik siswa, yaitu mengarahkan siswa untuk dapat memadukan keterampilan yang sudah dimiliki dengan keterampilan yang dicontohkan guru.

Pada pertanyaan selanjutnya menunjukkan sebanyak $92,12 \%$ siswa dan guru menjawab "sesuai", sedangkan sebanyak 7,88\%. Melalui hasil tersebut materi buku teks bahasa Indonesia revisi 2017 sesuai dngan karakteristik siswa SMP kelas VII A7. Melalui materi dalam buku teks siswa dapat memproduksi teks secara mandiri maupun berkelompok.

Pada pertanyaan kedelapan, didapatkan persentase sebagai berikut. 
Volume 8 Nomor 1, Februari 2018

P-ISSN : 2614-4743 (cetak) dan e-ISSN : 2614-2007 (online)

Sebanyak $87,27 \%$ meyatakan "sesuai", sedangkan sebanyak $12,73 \%$ menyatakan "tidak sesuai". Hal tersebut menunjukkan materi dalam buku teks sesuai dengan karakteristik siswa. Dengan mempelajari materi pada buku teks, siswa dapat menelaah dan menyunting melalui contoh yang ada dalam buku.

Selain itu, kesesuaian materi buku teks dengan karakteristik siswa sudah sangat sesuai. Hal tersebut tercermin dalam hasil persentase berikut. Sebanyak $95,75 \%$ siswa dan guru menjawab "sesuai", sedangkan sebanyak $4,25 \%$ menjawab kurang sesuai. Melalui hasil tersebut dapat diartikan bahwa materi dalam buku teks sudah sesuai dengan karakteristik siswa, yaitu mengarahkan siswa untuk dapat merevisi teks sesuai dengan struktur teks tersebut.

Terakhir, kesesuaian materi buku teks bahasa Indonesia revisi 2017 dengan karakteristik siswa menunjukkan hasil sesuai. Sebanyak $84,84 \%$ siswa dan guru menyatakan "sesuai", sedangkan 15,16\% siswa dan guru menyatakan "tidak sesuai". Dengan demikian, terdapat beberapa siswa yang belum dapat membuat rekonstruksi teks melalui membandingkan teks lain.

Di samping data-data tersebut, pertanyaan yang dijawab oleh guru kelas VII A7 melengkapi data kesesuaian materi buku teks bahasa Indonesia kelas VII pada bab 6, 7, dan 8. Berikut adalah hasil presentasenya. Pada pertanyaan pertama, bab enam dan delapan sebanyak $50 \%$ guru menyatakan "kurang sesuai", sedangkan bab 7 sebanyak $100 \%$ guru menyatakan "sesuai". Selanjutnya, materi pada bab 6 sudah "sesuai", sebanyak $100 \%$ guru menyatakan materi tersebut dapat mengarahkan siswa untuk berimajinasi. Sedangkan materi pada bab 7 dan 8 tidak dapat mengarahkan siswa untuk berimajinasi.

Hasil wawancara pada soal ketiga menunjukkan materi bab 6,7 , dan 8 pada buku teks sesuai dengan karakteristik siswa. Sebanyak 100\% guru menyatakan materi pada bab tersebut sudah mengarahkan siswa untuk dapat menarik kesimpulan. Pada pertanyaan keempat, guru menyatakan materi buku teks "kurang sesuai". Sebanyak $50 \%$ guru menyatakan materi pada buku teks belum dapat mengarahkan siswa untuk memiliki semua kecerdasan pada kecerdasan ganda.

Materi pada bab 6, 7, dan 8 sudah mengarahkan siswa untuk memiliki 16 sikap positif, yaitu $100 \%$ guru menyatakan sesuai dengan pertanyaan kelima. Begitu pula dengan pertanyaan keenam dan ketujuh, sebanyak $100 \%$ guru menyatakan materi pada bab 6, 7, dan 8 sudah mengarahkan siswa untuk dapat memadukan keterampilan yang dimiliki guru dan siswa dan memproduksi teks secara mandiri.

Pada pertanyaan selanjutnya menunjukkan sebanyak $100 \%$ guru menyatakan materi pada bab 6 dan 7 "sesuai" dengan karakteristik siswa, sedangkan materi pada bab 8 tidak dapat mengarahkan siswa untuk menelaah dan menyunting teks.

Pada pertanyaan kesembilan, materi pada bab 6,7, dan 8 sesuai dengan karakteristik siswa. Sebanyak 100\% guru menyatakan materi pada bab tersebut dapat mengarahkan siswa untuk dapat merevisi teks sesuai dengan strukturnya.

Terakhir, sebanyak $100 \%$ guru menyatakan materi pada bab 7 "sesuai dengan buku teks, sedangkan materi pada bab 6 dan 8 tidak dapat mengarahkan siswa untuk membuat rekonstruksi teks melalui membandingkan unsur-unsurnya.

Secara umum dapat disimpulkan bahwa materi buku teks bahasa Indonesia edisi revisi sudah sesuai dengan tuntutan Kurikulum 2013 (khususnya silabus bahasa Indonesia SMP/MTs kelas VII) dan sudah sesuai dengan karakteristik siswa kelas VII A7 di SMPN 1 Singaraja. Walaupun beberapa materi kurang sesuai dengan kedua hal tersebut, sudah seyogianya guru sebagai fasilitator dalam pembelajan dapat mengolah dan mengembangkan materi ajarnya sendiri. Terkait dengan hal tersebut, model silabus mata pelajaran bahasa Indonesia Kementerian Pendidikan dan Kebudayaan tahun 2017 menyatakan bahwa buku merupakan bahan ajar dan sumber 
informasi. Namun buku bukan satusatunya sumber belajar yang dapat digunakan di kelas. Guru dapat menyesuaikan materi buku teks dengan kondisi sekitar, model pembelajaran, dan karateristik siswa.

\section{SIMPULAN DAN SARAN}

Ada beberapa hal yang menjadi simpulan dalam penelitian ini. Pertama, permasalahan pertama mengenai kesesuaian materi buku teks siswa bahasa Indonesia SMP/MTs kelas VII Kurikulum 2013 edisi 2017 dengan tuntutan kurikulum terletak pada $\mathrm{KI}, \mathrm{KD}$, dan penilaian otentik. Tedapat beberapa materi yang kurang sesuai dengan $\mathrm{KI} 3$ dan KI 4 dalam Kurikulum 2013. Hal tersebut tercermin dalam $\mathrm{KD} 3.3,3.9$, 3.11 dan 4.3 dalam Kurikulum 2013 (terdapat pada bab 2, 5, dan 6). Di samping itu, peneliti menemukan kekurangsesuaian pada penilaian autentik kompetensi pengetahuan dan kompetensi keterampilan.

Kedua, permasalahan kedua mengenai kesesuaian materi buku teks bahasa Indonesia SMP/MTs kelas VII Kurikulum 2013 edisi 2017 dengan karakteristik siswa kelas VII A7 di SMPN 1 Singaraja terletak pada aspek kognitif/pengetahuan, aspek afektif/sikap, dan aspek psikomotor/keterampilan. Materi buku teks bahasa Indonesia SMP/MTs kelas VII Kurikulum 2013 edisi 2017 sesuai dengan karakteristik siswa kelas VII A7 di SMPN 1 Singaraja, walaupun belum secara maksimal. Karena terdapat beberapa karakteristik yang belum berkembang pada semua siswa kelas VII A7 di SMPN 1 Singaraja.

Berdasarkan temuan-temuan dalam penelitian ini, terdapat beberapa saran yang dapat disampaikan. (1) Para penulis buku sebaiknya lebih teliti dalam menyusun buku, sehingga menghasilkan buku yang lebih berkualitas lagi. Di samping itu, guru diharapkan menyiasati ketidaksesuaian dan kekurangsesuaian buku teks dengan menggunakan teks atau buku lain, sehingga siswa mampu mencapai kompetensi yang diharapkan oleh guru. (2) Peneliti lain diharapkan untuk melakukan penelitian sejenis terkait dengan permasalahan tingkat keterbacaan, kemudahan, dan keterpahaman buku teks. Selain itu, objek lain yang dapat diteliti, yaitu unsur kebahasaan buku teks yang dilihat dari beberapa aspek.

\section{Daftar Pustaka}

Danim, Sudarwan. 2013. Perkembangan Peserta Didik. Bandung: Alfabeta.

Daryanto, Aris Dwicahyono.2014. Pengembangan Perangkat Pembelajaran: Silsbus, RPP, PHB, Bahan Ajar. Yogyakarta: Gava Media.

Hidayat, Sholeh. 2013. Pengembangan Kurikulum Baru. Bandung: Remaja Rosdakarya.

Kemendikbud. 2017. Bahasa Indonesia Edisi Revisi. (tidak diterbitkan).

Mudlofir, A, (2011). Aplikasi Pengembangan Kurikulum Tingkat Satuan Pendidikan dan Bahan Ajar dalam Pendidikan Agama Islam. Jakarta: Raja Grafindo Persada.

Mulyasa. 2011. Bahan Ajar untuk Siswa. Surabaya: Kata Pena.

Nurmutia, Halida Eka. 2013. Analisis Materi, Penyajian, dan Bahasa Buku Teks Matematika Kelas X Di Kabupaten Rembang Tahun Ajaran 2012/2013. Skripsi (tidak diterbitkan). Semarang: UNESA.

Prayoga, Amrih. 2011. Analisis Kelayakan Isi Buku Teks Pelajaran Fisika SMA. Skripsi (tiak diterbitkan). Semarang: IAIN Walisongo.

Sholeh, K. (2006). Relevansi Materi Pembelajaran Bahasa Indonesia dalam Buku Ajar Bahasa Indonesia 1 untuk SMK/MAK Kelas X Terbitan Depdiknas dengan Kurikulum Tingkat Satuan Pendidikan. Skripsi (tidak diterbitkan). Purworejo :FKIP Universitas Muhammadiyah Purworejo.

Sriasih, Sang Ayu Putu. 2012. Telaah Buku Teks. Modul (tidak diterbitkan). Singaraja: Undiksha.

Trenis, Ni Nyoman. 2012. Kesalahan Bahasa Indonesia dam Buku Teks 'IPS Terpadu' Karya Tim Abdi Guru 
Penerbit Erlangga. Skripsi (tidak diterbitkan). Singaraja: Udiksha.

Yusuf, Syamsu dan Nani M. Sugandhi. 2013. Perkembangan Peserta Didik. Jakarta: Rajawali Pers.

Daftar Laman

Lampiran permendikbud nomor 24 tahun 2016.

https://agungagmi.blogspot.co.id/201 7/05/lampiran-permendikbud-nomor24-tahun.html. Diakses pada tanggal 2 Februari 2018.

Lidwita. 2015.

http://www.slideshare.net/lidwita/24analisis-buku-guru-dan-siswa-mapelrev-35113361. Diakses pada tanggal 26 Februari 2015.
Model Silabus Mata Pelajaran Bahasa Indonesia SMP/MTs 2017. https://forumgurunusantara.blogspot. com/2016/09/download-silabussmpmts-kurikulum-2013.html. Diakses pada tanggal 18 Januari 2018.

Nurmutia, Halida Eka. 2013. www.google.com. Diakses pada tanggal 19 Juni 2014.

Perubahan K13 (Kurikulum 2013 Update Tahun 2017). https://kreatifitastanpabatas17.blogs pot.co.id/2017/08/9-perubahan-k13kurikulum-2013-update.html. Diakses pada tanggal 2 Fenruri 2018. Prayoga, Amrih. 2011. www.google.com. Diakses pada tanggal 19 Juni 2014. 